\title{
Comparison of short- and long-term effects of different dietary fats on the hepatic uptake and metabolism of chylomicron remnants in rats
}

\author{
Marc S. Lambert, Michael A. Avella, Kathleen M. Botham* and Peter A. Mayes \\ Division of Biochemistry, Department of Veterinary Basic Sciences, The Royal Veterinary College, University of London, \\ London NW1 OTU, UK
}

(Received 20 March 1997 - Revised 11 August 1997 - Accepted 18 September 1997)

\begin{abstract}
The uptake and metabolism of $\left[{ }^{14} \mathrm{C}\right]$ oleate-labelled chylomicron remnants derived from olive oil, maize oil, palm oil, fish oil or butter fat was investigated using perfused livers from rats fed on the corresponding fat-supplemented diet (providing $40 \%$ of the dietary energy) or a low-fat diet for $21 \mathrm{~d}$. The percentage of added $\left[{ }^{14} \mathrm{C}\right]$ oleate-labelled remnant removed from the perfusate was similar for livers from rats fed on the fat-supplemented diets irrespective of the type of fat fed, whereas livers from rats fed on the low-fat diet removed more labelled fish oil and butter fat remnants than olive, maize or palm oil remnants. Following hepatic uptake in the fatsupplemented groups, the oxidation of $\left[{ }^{14} \mathrm{C}\right]$ oleate-labelled remnant lipid from maize oil, fish oil, and butter fat remnants was greater than that of the lipids from olive and palm oil remnants, although only the oxidation of lipids from maize and palm oil remnants was increased by prior fat-supplementation of the diet. In addition, the livers from rats fed on the fish-oil-supplemented diet incorporated more $\left[{ }^{14} \mathrm{C}\right]$ oleate-labelled remnant lipid into phospholipid compared with the livers from rats fed on the other fat-supplemented diets or the low-fat diets. These investigations show that both prior fat feeding and the composition of the fat fed, as well as the fatty acid composition of the chylomicron remnant particles themselves, influence the uptake and metabolism of chylomicron remnants by the liver.
\end{abstract}

Perfused rat liver: Dietary fat: Chylomicrons

Chylomicron remnants are formed by the action of lipoprotein lipase (EC 3.1.1.34) on triacylglycerol-rich chylomicrons, and are responsible for the delivery of dietary cholesterol and some triacylglycerol to the liver (Redgrave, 1970). Several studies have shown that the type of dietary fat from which chylomicrons and chylomicron remnants are derived influences their removal by the liver. Livers from dogs and rats are reported to remove $\left[{ }^{3} \mathrm{H}\right]$ - or $\left[{ }^{14} \mathrm{C}\right]$ fatty acid derived from labelled chylomicrons more rapidly when they are derived from cream as compared with maize oil (Nestel \& Scow, 1964; Floren \& Nilsson, 1977). Also, in human subjects, retinyl palmitate-labelled chylomicrons and chylomicron remnants derived from soyabean oil or cream are removed more rapidly from the circulation than those derived from olive oil (De Bruin et al. 1993). In this laboratory we have shown that $\left[{ }^{14} \mathrm{C}\right]$ oleate-labelled fish oil and butter fat chylomicron remnants (labelled predominantly in triacylglycerol) are taken up by the perfused rat liver more rapidly than those derived from olive, maize or palm oils (Lambert et al. 1995). Taken together these studies show that chylomicron remnants derived from milk fat (cream or butter fat), soyabean oil or fish oil tend to be taken up more rapidly by the liver than those derived from olive, maize or palm oils. As fat-supplemented diets were not used in these studies, the differential uptake of the remnants can be attributed to the fatty acid composition of the particles themselves, which is largely determined by the type of fat from which they are derived (Lambert et al. 1996).

In the longer term the type of dietary fat consumed is likely to influence the fatty acid composition of the liver membranes (Kritchevsky et al. 1988; Hostmark et al. 1989) and the activity of hepatic lipase (EC 3.1.1.3) (Coiffer $e t$ al. 1987; Bravo et al. 1997). This may have additional effects 
on the rates of removal and metabolism of chylomicron remnants by the liver. Investigations with normolipidaemic human subjects have shown that retinyl palmitate-labelled apolipoprotein B48-containing lipoproteins (chylomicrons and chylomicron remnants) are removed from the circulation more rapidly when diets enriched in $n-6$ and $n-3$ polyunsaturated fatty acids are compared with saturated fatty acids (Weintraub et al. 1988; Demacker et al. 1991), and in a further investigation, the clearance of retinyl palmitate-labelled chylomicrons was reported to be similar in human subjects consuming fish oil or olive oilsupplemented diets (Harris \& Muzio, 1993).

Other evidence suggests that the type of fatty acids in the remnant particle and in the diet may affect the metabolism of chylomicron remnant lipids within the liver. In our previous work we showed that perfused livers oxidized four- to sevenfold more $\left[{ }^{14} \mathrm{C}\right]$ oleate-labelled lipids from chylomicron remnants derived from olive oil, fish oil and butter fat as compared with maize or palm oils. In addition, more of the hepatic $\left[{ }^{14} \mathrm{C}\right]$ oleate-labelled lipid taken up from fish oil remnants was converted to labelled phospholipid when compared with that from olive oil, maize oil, palm oil, or butter fat remnants (Lambert et al. 1995). Furthermore, Moir et al. (1995) showed that rats consuming diets enriched with $n-6$ or $n-3$ polyunsaturated fatty acids oxidized more $\left[{ }^{14} \mathrm{C}\right]$ oleate from VLDL and chylomicron remnants (labelled in cholesteryl- $\left[{ }^{14} \mathrm{C}\right]$ oleate) and incorporated less into triacylglycerol, when compared with rats consuming diets enriched in saturated fatty acids. We believe more evidence is required to provide a better understanding of the longer-term effects of a broad range of different dietary fats on chylomicron remnant uptake and metabolism by the liver.

In the present study the uptake and metabolism of $\left[{ }^{14} \mathrm{C}\right]$ oleate-labelled chylomicron remnants derived from olive oil, maize oil, palm oil, fish oil or butter fat were compared using isolated perfused livers from rats fed on the corresponding fat-supplemented diet for $21 \mathrm{~d}$ before the experiments (e.g. metabolism of olive oil remnants by perfused livers from rats fed on an olive oil-supplemented diet). The results were also contrasted with those obtained using livers from rats fed on a standard low-fat diet. This experimental design enabled the effects of the longer-term adaptive changes in the liver on remnant lipid metabolism to be compared with the immediate effects of changes in the fatty acid composition of the remnants themselves.

\section{Materials and methods}

\section{Animals and materials}

Male Wistar rats were kept under constant day length $(12 \mathrm{~h})$ and temperature $\left(25^{\circ}\right)$ and used for chylomicron and chylomicron remnant preparation $(350-370 \mathrm{~g})$, and as blood perfusate donors $(350-450 \mathrm{~g}) \cdot\left[1{ }^{14} \mathrm{C}\right]$ oleic acid was obtained from Amersham International, Amersham, Bucks., UK. Sodium pentobarbital, cholesterol oxidase (EC 1.1.3.17), ampicillin and menhaden fish oil were obtained from Sigma Chemical Company, Poole, Dorset, UK. Triacylglycerol and cholesterol assay kits were from Boehringer Mannheim, Lewes, E. Sussex, UK. Palm oil was obtained from Rhone Poulenc, Manchester, Lancs., UK. Olive oil, maize oil, and butter were obtained from domestic suppliers. The scintillant Emulsifier 299 and the $\mathrm{CO}_{2}$ absorber Carbo-sorb were obtained from Packard Instruments, Reading, Berks., UK. All other chemicals were obtained from BDH, Dagenham, Essex, UK.

\section{Dietary studies}

Fat-supplemented diets ( $40 \%$ of the energy value of the diet as fat) were stored at $4^{\circ}$ and prepared every $5-7 \mathrm{~d}$ by mixing $1 \mathrm{~g}$ olive oil, maize oil, palm oil, fish oil or filtered butter fat with $4.71 \mathrm{~g}$ of a standard low-fat rat diet (digestible energy $12 \cdot 10 \mathrm{~kJ} / \mathrm{g}$; Quest Nutrition, Canterbury, Kent, UK). The standard energy value for fats was taken to be $38 \mathrm{~kJ} / \mathrm{g}$ (Mills et al. 1986). Rats (170-188 g body weight) were placed in individual cages and were provided with $30 \mathrm{~g} / \mathrm{d}$ of the fat-supplemented or the standard low-fat diets for $21 \mathrm{~d}$. The rats consumed similar amounts $(24$ $30 \mathrm{~g} / \mathrm{d}$ ) of the fat-supplemented or low-fat diets which were sufficient to meet the recommended daily requirements for protein and all other nutrients, and during the $21 \mathrm{~d}$ they maintained similar growth rates $(6 \cdot 0-6 \cdot 8 \mathrm{~g} / \mathrm{d})$.

\section{Preparation of $\left[{ }^{14}\right.$ CJoleate-labelled chylomicron remnants}

Olive oil, maize oil, palm oil, fish oil or filtered butter fat $(0.5 \mathrm{ml})$ supplemented with $\alpha$-tocopherol $(4 \mathrm{mg} / \mathrm{ml})$ was tube-fed to a rat (maintained on a standard low-fat diet). After approximately $1 \mathrm{~h}$ the rat was anaesthetized with sodium pentobarbital (60 $\mathrm{mg} / \mathrm{kg}$ intraperitoneally), and the thoracic duct was cannulated (Bollman et al. 1948). When the chyle was flowing satisfactorily, $\left[{ }^{14} \mathrm{C}\right]$ oleic acid (3.7 MBq) neutralized with $\mathrm{KOH}(0.1 \mathrm{M})$ and emulsified with sodium taurocholate $(10 \mathrm{mg})$, plus a further $0.5 \mathrm{ml}$ of the same oil or fat fed initially, was injected through the wall of the pyloric region of the stomach. The abdominal wall was then sutured and the rat was placed in a restraining cage where it had access to saline $(9 \mathrm{~g} \mathrm{NaCl} / 1)$ for $5 \mathrm{~h}$, and water $16-18 \mathrm{~h}$. The chyle (containing ampicillin $0.1 \mathrm{mg} / \mathrm{ml}$ ) was layered $(2 \mathrm{ml} /$ tube) under $\mathrm{NaCl}$ (density $1.006 \mathrm{~g} / \mathrm{ml})$ in $6.5 \mathrm{ml}$ polyallomer tubes and ultracentrifuged at $20000 \mathrm{rev} . / \mathrm{min}$ for $21 \mathrm{~min}\left(6 \times 10^{5} \mathrm{~g}\right)$ in a fixedangle rotor at a temperature of $12^{\circ}$. [ $\left.{ }^{14} \mathrm{C}\right]$ oleate-labelled large chylomicrons (diameter $>100 \mathrm{~nm}$ ) free from intestinal VLDL (small chylomicrons) were then removed by slicing the top $10-15 \mathrm{~mm}$ of the tubes using a Beckman tube slicer.

$\left[{ }^{14} \mathrm{C}\right]$ oleate-labelled chylomicron remnants were prepared from these labelled large chylomicrons in functionally hepatectomized rats as described previously (Lambert et al. 1996). Their serum (containing labelled chylomicron remnants) was layered under $\mathrm{NaCl}(1.006 \mathrm{~g} / \mathrm{ml})$ in polyallomer tubes and ultracentrifuged for $6 \times 10^{7} \mathrm{~g}$ at $12^{\circ}$, and further purified by ultracentrifugation for $3.2 \times 10^{7} \mathrm{~g}$ at $12^{\circ}$. Labelled chylomicron remnants were isolated from the top fraction $(1 \mathrm{ml})$ by tube slicing. Contamination of the labelled remnants with VLDL and intermediate density lipoprotein (IDL) was minimized by 
Table 1. Fatty acid composition $(\mathrm{g} / 100 \mathrm{~g}$ total fatty acids) of chylomicron remnants derived from olive, maize, palm or fish oils, or butter fat in rats*

(Mean values with their standard errors for three independent preparations)

\begin{tabular}{|c|c|c|c|c|c|c|c|c|c|c|}
\hline \multirow[b]{3}{*}{ Fatty acid } & \multicolumn{10}{|c|}{ Type of chylomicron remnant } \\
\hline & \multicolumn{2}{|c|}{ Olive oil } & \multicolumn{2}{|c|}{ Maize oil } & \multicolumn{2}{|c|}{ Palm oil } & \multicolumn{2}{|c|}{ Fish oil } & \multicolumn{2}{|c|}{ Butter fat } \\
\hline & Mean & $\mathrm{SE}$ & Mean & SE & Mean & $\mathrm{SE}$ & Mean & SE & Mean & SE \\
\hline $\begin{array}{l}14: 0 \\
16: 0 \\
18: 0 \\
18: 1 \\
18: 2 \\
20: 5 \\
22: 6\end{array}$ & $\begin{array}{r}0.89^{\mathrm{a}} \\
18.53^{\mathrm{a}} \\
5.12^{\mathrm{a}} \\
46.22^{\mathrm{a}} \\
18.16^{\mathrm{a}} \\
0.79^{\mathrm{a}} \\
2.62^{\mathrm{a}}\end{array}$ & $\begin{array}{l}0.16 \\
0.23 \\
0.33 \\
3.80 \\
1.12 \\
0.03 \\
0.46\end{array}$ & $\begin{array}{r}1.01^{\mathrm{a}} \\
20.25^{\mathrm{a}} \\
5.11^{\mathrm{a}} \\
22.92^{\mathrm{b}} \\
33.02^{\mathrm{b}} \\
1.62^{\mathrm{a}} \\
2.57^{\mathrm{a}}\end{array}$ & $\begin{array}{l}0.09 \\
0.50 \\
0.24 \\
0.79 \\
0.85 \\
0.31 \\
0.80\end{array}$ & $\begin{array}{r}1.01^{\mathrm{a}} \\
29.12^{\mathrm{b}} \\
4.99^{\mathrm{a}} \\
33.86^{\mathrm{c}} \\
18.14^{\mathrm{a}} \\
0.74^{\mathrm{a}} \\
2.50^{\mathrm{a}}\end{array}$ & $\begin{array}{l}0.04 \\
0.91 \\
0.23 \\
0.63 \\
1.50 \\
0.04 \\
0.36\end{array}$ & $\begin{array}{r}3.04^{\mathrm{b}} \\
20.11^{\mathrm{a}} \\
5.12^{\mathrm{a}} \\
15.69^{\mathrm{d}} \\
14.89^{\mathrm{a}} \\
12.75^{\mathrm{b}} \\
7.00^{\mathrm{b}}\end{array}$ & $\begin{array}{l}0.51 \\
0.37 \\
0.53 \\
0.63 \\
1.49 \\
1.31 \\
0.36\end{array}$ & $\begin{array}{c}4.84^{\mathrm{b}} \\
27.98^{\mathrm{b}} \\
8.30^{\mathrm{b}} \\
21.11^{\mathrm{bd}} \\
16.51^{\mathrm{a}} \\
1.44^{\mathrm{a}} \\
2.64^{\mathrm{a}}\end{array}$ & $\begin{array}{l}1.51 \\
1.66 \\
0.30 \\
0.53 \\
1.43 \\
0.65 \\
0.26\end{array}$ \\
\hline
\end{tabular}

$a, b, c, d$ Mean values within a row not sharing a common superscript letter were significantly different, $P<0.05$.

* For details of procedures, see pp. 204-206.

using post-absorptive rats and two centrifugation steps. The fatty acid composition of the remnants was analysed as described previously (Lambert et al. 1996), and a summary showing the major fatty acids is provided in Table 1 . No significant differences in cholesterol and triacylglycerol content were observed between the different types of remnants, and the samples added to the perfusate of isolated perfused livers were standardized to contain 1$1.5 \mu \mathrm{mol}$ total cholesterol and 3-6 $\mu \mathrm{mol}$ triacylglycerol. The percentage distribution of $\left[{ }^{14} \mathrm{C}\right]$ oleate between the major remnant lipids was as follows: triacylglycerol (80$90 \%$ ), mono- and diacylglycerols (3-5\%), non-esterified fatty acid $(3-4 \%)$, and phospholipid $(2-3 \%)$, and there were no significant differences between any of the different types of remnants prepared.

\section{Liver perfusions}

The methods for the surgical isolation of the rat liver have been described previously (Lambert et al. 1995). In the present experiments the blood perfusate $(115 \mathrm{ml})$ was derived from rats which had been fed on a standard lowfat diet, dialysed against a Krebs and Henseleit bicarbonate buffer containing (mM): $\mathrm{NaCl} 118, \mathrm{KCl} 4.7, \mathrm{CaCl}_{2} 1.32$, $\mathrm{MgSO}_{4} 1 \cdot 2, \mathrm{Na}_{2} \mathrm{HCO}_{3} 24, \mathrm{KH}_{2} \mathrm{PO}_{4} 1 \cdot 2$, glucose $13 \cdot 9$, and plasma amino acids $670 \mathrm{mg} / \mathrm{l}$. The packed cell volume was adjusted to $35 \%$ by the addition of this buffer containing bovine serum albumin $(60 \mathrm{~g} / \mathrm{l})$. The liver was perfused at a flow rate of $1.5 \mathrm{ml} / \mathrm{min}$ per $\mathrm{g}$ and the blood $p \mathrm{O}_{2}$ was maintained at $100 \mathrm{mmHg}(13.3 \mathrm{kPa})$ by gassing with a mixture of $\mathrm{O}_{2}-\mathrm{CO}_{2}(19: 1, \mathrm{v} / \mathrm{v})$ and air- $\mathrm{CO}_{2}(19: 1, \mathrm{v} / \mathrm{v})$. At zero time, $\left[{ }^{14} \mathrm{C}\right]$ oleate-labelled chylomicron remnants prepared from one of the test oils or butter fat were added to the recirculating perfusate, and the liver was perfused for a further $4 \mathrm{~h}$. During the perfusion, samples were removed from the perfusate at 1,2 and $4 \mathrm{~h}$ and the serum was separated from the erythrocytes by centrifugation at $3000 \mathrm{~g}$ for $15 \mathrm{~min}$. The ${ }^{14} \mathrm{CO}_{2}$ released by the liver was collected by passing the respiratory gases through two absorbers in series containing $2 \mathrm{M}-\mathrm{NaOH}(30-40 \mathrm{ml})$ which were changed at $1 \mathrm{~h}$ intervals to ensure $100 \%$ recovery. After
$4 \mathrm{~h}$ the experiment was terminated, and the liver was flushed free of blood with the bicarbonate buffer containing bovine serum albumin $(10 \mathrm{~g} / \mathrm{l})$.

\section{Analytical methods}

Lipid extracts were prepared from the serum and the liver using 20 volumes of chloroform-methanol $(2: 1, \mathrm{v} / \mathrm{v})$, and partitioned with 0.4 volumes of $0.03 \mathrm{M}-\mathrm{HCl}$. Portions of the chloroform phase were dried under $\mathrm{N}_{2}$ and separated into lipid classes by TLC using silica gel $\mathrm{G}$ and hexane-diethyl ether-formic acid (40:10:1, by vol.) as the developing solvent. After location with $I_{2}$ the silica-gel bands were transferred into scintillation vials for counting. Dried lipid extracts and silica-gel bands from TLC were counted for radioactivity with a toluene-based scintillant $(18 \mathrm{ml})$ containing $3 \mathrm{~g}$ 2,5-diphenyloxazole $/ 1$ and $0.25 \mathrm{~g}$ 1,4-bis(4-methyl-5-phenyloxazol-2-yl)benzene/l. Phospholipid bands from TLC were extracted from the silica gel $G$ in distilled water $(1 \mathrm{ml})$ and counted in the scintillant Emulsifier 299.

The triacylglycerol content in extracts of liver was determined by a semi-enzymic method which involved an initial chemical hydrolysis. Chloroform extracts of liver and tripalmitin standards were made up to a volume of $6 \mathrm{ml}$ in centrifuge tubes, and phospholipids were removed by the addition of $50 \mathrm{mg}$ silica gel (previously activated in an oven at $105^{\circ}$ for $2 \mathrm{~h}$ ). After vigorous mixing, the tubes were centrifuged at $3000 \mathrm{~g}$ for $10 \mathrm{~min}$, and $3 \mathrm{ml}$ of the supernatant fraction was dried under a stream of $\mathrm{N}_{2}$ at $60^{\circ}$. Triacylglycerol hydrolysis was achieved by the addition of ethanolic $\mathrm{KOH}(1 \mathrm{ml} ; 1.25 \mathrm{~g} / 1$ ethanol) and incubation at $60^{\circ}$ for $30 \mathrm{~min} . \mathrm{H}_{2} \mathrm{SO}_{4}(1 \mathrm{ml}, 1.4 \mathrm{M})$ was then added to neutralize each extract, and the released fatty acids were partitioned in diethylether $(4 \mathrm{ml})$. The tubes were shaken for 5-10 min and the upper diethyl ether layer was removed using a pasteur pipette. The remaining diethyl ether was evaporated under a stream of $\mathrm{N}_{2}$. Following this procedure, portions of the aqueous liver extracts (containing glycerol released from the triacylglycerol) and aqueous serum samples could be assayed enzymically for triacylglycerol 
content using the Boehringer Mannheim assay kit. Cholesterol mass was determined enzymically in aqueous samples and portions of the dried lipid extracts suspended in propan-2-ol $(200 \mu \mathrm{l})$ according to the method of Trinder (1969). The total cholesterol was measured in these samples by the addition of cholesterol esterase ( $E C$ 3.1.1.13) reagent. The ${ }^{14} \mathrm{CO}_{2}$ produced by the liver was measured according to previously described methods (Lambert et al. 1995).

\section{Statistical analyses}

Results are expressed as means with their standard errors. Statistical significance within a group was determined by one-way ANOVA followed, where appropriate, by the Fischer's test of least difference for multiple comparisons to compare means between groups using Statview software, version 1.03, 1988 (Abacus Concepts Inc., Berkeley, CA, USA). A $P$ value $<0.05$ was considered to be statistically significant.

\section{Results}

Serum and liver triacylglycerol concentrations in rats fed on a fat-supplemented or low-fat diet

Rats fed on the olive oil, maize oil, palm oil or butter fatsupplemented diets had serum triacylglycerol concentrations which ranged between 1.06 and $1.17 \mathrm{mM}$, while those fed on the fish oil-supplemented diet were $44 \%$ lower at $0.60 \mathrm{mM}$ (Table 2). In all cases the serum triacylglycerol concentration in rats fed on the fat-supplemented diets were lower (approximately $50 \%$ less) than those fed on the lowfat diet. The liver weights of rats fed on the butter fatsupplemented diet were not significantly different to those from rats fed on the low-fat diet, although livers from both these dietary groups weighed significantly more than livers from rats fed on any of the other fat-supplemented diets. The livers from rats fed on olive or fish oil contained less triacylglycerol when expressed both as total $\mu \mathrm{mol}$ and $\mu \mathrm{mol} / \mathrm{g}$ liver, than those from rats fed on the butter fatsupplemented diet, and these latter livers contained more triacylglycerol than livers from rats fed on a low-fat diet (Table 2).

Removal of $\left[{ }^{14}\right.$ Cloleate-labelled chylomicron remnants by perfused livers from rats fed on a fat-supplemented or a low-fat diet

Livers from rats fed on the low-fat diet removed $\left[{ }^{14} \mathrm{C}\right]$ oleate-labelled remnants rapidly from the perfusate over the $4 \mathrm{~h}$ experimental period (Fig. 1), and their rates of removal were influenced by the type of fat from which they were derived. After $4 \mathrm{~h}$, butter fat remnants were removed to the greatest extent ( $47 \%$ ), followed by fish oil remnants $(42 \%)$, palm oil remnants (39\%), olive oil remnants $(35 \%)$ and maize oil remnants $(31 \%)$. When these values were compared with those obtained using rats fed on the corresponding fats in the diet, livers from rats fed on maize oil removed more of the $\left[{ }^{14} \mathrm{C}\right]$ oleate-labelled remnants from the perfusate in $4 \mathrm{~h}$ (Fig. 1(b)), those from rats fed on the butter fat diet removed less (Fig. 1(e)), while those from rats fed on the olive, palm and fish oil diets showed no significant change (Fig. 1 (a,c,d)). These effects of fat-feeding eliminated the differences in the uptake of remnants of different fatty acid composition found with livers from rats fed on the low-fat diet, so that all the different types of remnants tested were removed at similar rates by the livers adapted to longer-term fat feeding.

These results were confirmed by measurements of the recovery of ${ }^{14} \mathrm{C}$ in the livers on termination of perfusion after $4 \mathrm{~h}$. For the livers from rats fed on a low-fat diet, significantly more ${ }^{14} \mathrm{C}$ was recovered from labelled fish oil or butter fat remnants than from olive or maize oil remnants (Table 3). However, in the same period, the percentage of ${ }^{14} \mathrm{C}$ recovered in the livers from rats fed on each of the fatsupplemented diets was similar, reflecting their comparable disappearance from the perfusate (Fig. 1).

\section{Metabolism of $I^{14} \mathrm{C}$ loleate-labelled chylomicron remnant lipids by perfused livers from rats fed on a fat- supplemented or a low-fat diet}

Overall, the effect of supplementation of the diets with fat was to decrease the difference in the oxidation of the

Table 2. Triacylglycerol content of the serum and livers of rats fed on a fat-supplemented diet or a low-fat diet; (Mean values with their standard errors; numbers of determinations are given in parentheses)

\begin{tabular}{|c|c|c|c|c|c|c|c|c|}
\hline & \multirow{2}{*}{\multicolumn{2}{|c|}{$\begin{array}{l}\text { Serum triacylglycerol } \\
(\mathrm{mmol} / \mathrm{l})\end{array}$}} & \multirow{2}{*}{\multicolumn{2}{|c|}{ Liver weight (g) }} & \multicolumn{4}{|c|}{ Liver triacylglycerol } \\
\hline & & & & & \multicolumn{2}{|c|}{ (Total $\mu \mathrm{mol}$ ) } & \multicolumn{2}{|c|}{ ( $\mu \mathrm{mol} / \mathrm{g}$ liver) } \\
\hline & Mean & SE & Mean & SE & Mean & SE & Mean & SE \\
\hline $\begin{array}{l}\text { Olive oil } \\
\text { Maize oil } \\
\text { Palm oil } \\
\text { Fish oil } \\
\text { Butter fat } \\
\text { Low-fat }\end{array}$ & $\begin{array}{l}1.12(6)^{\star} \\
1.10(4)^{\star} \\
1.06(6)^{\star} \\
0.60(2) \\
1.17(5)^{\star} \\
2.06(4)\end{array}$ & $\begin{array}{c}0.06 \\
0.15 \\
0.09 \\
(0.5-0.7) \S \\
0.06 \\
0.21\end{array}$ & $\begin{array}{l}11.80(11)^{\star} \dagger \\
12.67(12)^{\star} \dagger \\
12.02(11)^{\star} \dagger \\
12.53(8)^{\star} \dagger \\
14.33(12) \\
13.89(9)\end{array}$ & $\begin{array}{l}0.32 \\
0.24 \\
0.28 \\
0.39 \\
0.57 \\
0.27\end{array}$ & $\begin{array}{c}66.52(4) \dagger \\
100.14(4)^{\star} \\
89.94(4) \\
54.86(4) \dagger \\
214.71(4)^{\star} \\
44.10(4)\end{array}$ & \begin{tabular}{r|}
18.25 \\
22.41 \\
35.54 \\
14.36 \\
91.85 \\
4.69
\end{tabular} & $\begin{array}{c}5.40 \dagger \\
7.80^{\star} \\
7.48 \\
4.15 \dagger \\
16 \cdot 68^{\star} \\
3 \cdot 11\end{array}$ & $\begin{array}{l}1.25 \\
1.51 \\
2.65 \\
0.95 \\
5.01 \\
0.26\end{array}$ \\
\hline
\end{tabular}

* Mean values were significantly different from that for the low-fat diet, $P<0.05$.

+ Mean values were significantly different from that for the butter fat diet, $P<0.05$

‡ For details of procedures, see pp. 204-206.

$\S$ Range is given due to the small number in this group. 

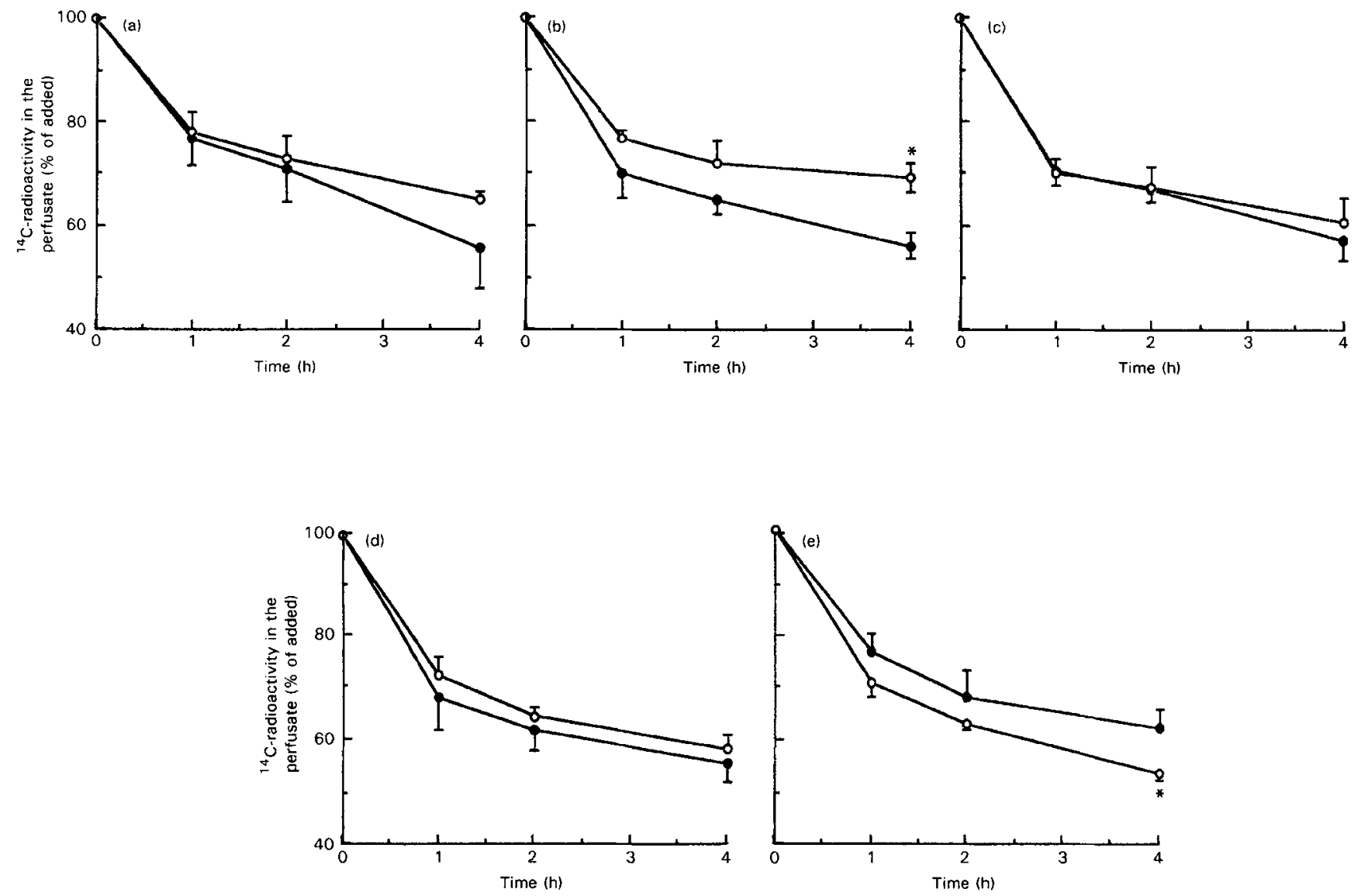

Fig. 1. Removal of $\left[{ }^{14} \mathrm{C}\right]$ oleate-labelled remnants from the perfusate of isolated livers derived from rats fed on a low-fat or fat-supplemented diet. Livers from rats fed on a low-fat diet $(O)$ or a fat-supplemented diet $(-)$ were perfused with $\left[{ }^{14} \mathrm{C}\right]$ oleate-labelled remnants derived from (a) olive oil, (b) maize oil, (c) palm oil, (d) fish oil, (e) butter fat as described on p. 205. Values are means with their standard errors represented by vertical bars for the following numbers of perfusions; low-fat diet: olive oil remnants $n 5$, maize oil remnants $n 4$, palm oil remnants $n 6$, fish oil remnants $n$ 4, butter fat remnants $n 6$; fat-supplemented diets: olive oil $n 4$, maize oil $n 6$, palm oil $n 4$, fish oil $n 4$, and butter fat $n 4$. Mean values were significantly different from corresponding fat-supplemented diet, ${ }^{*} P<0.05$.

Table 3. Uptake of $\left[{ }^{14} \mathrm{C}\right]$ oleate-labelled chylomicron remnants by perfused livers from rats fed on a low-fat or fatsupplemented diet ${ }^{\star}$

(Mean values with their standard errors after $4 \mathrm{~h}$ perfusion; numbers of perfusions are given in parentheses)

\begin{tabular}{|c|c|c|c|c|c|}
\hline \multirow[b]{3}{*}{ Source of remnants } & \multicolumn{4}{|c|}{$\begin{array}{c}\text { Remnant }\left[{ }^{14} \text { C]oleate-labelled lipids recovered in the liver }\right. \\
\text { (\% of added) }\end{array}$} & \multirow{3}{*}{$\begin{array}{l}\text { Percentage change } \\
\text { (fat supplemented } \\
\text { v. low-fat diet) }\end{array}$} \\
\hline & \multicolumn{2}{|c|}{ Low-fat diet } & \multicolumn{2}{|c|}{ Fat-supplemented diet } & \\
\hline & Mean & SE & Mean & $\mathrm{SE}$ & \\
\hline $\begin{array}{l}\text { Olive oil } \\
\text { Maize oil } \\
\text { Paim oil } \\
\text { Fish oil } \\
\text { Butter fat }\end{array}$ & $\begin{array}{l}25.09^{\mathrm{a}}(4) \\
26.00^{\mathrm{a}}(6) \\
30.08^{\mathrm{ab}}(4) \\
35.90^{\mathrm{b}}(4) \\
37.13^{\mathrm{b}}(4)\end{array}$ & $\begin{array}{l}1.39 \\
1.72 \\
4.53 \\
2.41 \\
1.98\end{array}$ & $\begin{array}{l}35.91(5) \\
30.84(6) \\
35.42(6) \\
34.72(4) \\
32.26(6)\end{array}$ & $\begin{array}{l}5.83 \\
2.31 \\
4.23 \\
0.96 \\
3.73\end{array}$ & $\begin{array}{r}+43.12 \\
+18.62 \\
+17.75 \\
-3.39 \\
-15.09\end{array}$ \\
\hline
\end{tabular}

${ }^{a, b}$ Mean values within a column not sharing a common superscript letter were significantly different, $P<0.05$.

* For details of procedures, see pp. 204-206.

individual $\left[{ }^{14} \mathrm{C}\right.$ oleate-labelled remnant lipids to ${ }^{14} \mathrm{CO}_{2}$ observed when rats fed on the low-fat diets were used (Fig. 2). Nevertheless, the livers from rats fed on fish oil still oxidized more of their corresponding $\left[{ }^{14} \mathrm{C}\right]$ oleatelabelled remnant lipids than those from rats fed on the olive oil or palm oil supplemented diets (Fig. 2(a)), and similar differences were observed when the results were expressed as a percentage of the ${ }^{14} \mathrm{C}$ in the liver (Fig. 2(b)). In addition, oxidation was also increased substantially in livers from rats fed on the maize or palm oil-supplemented diets as compared with the low-fat diets, although oxidation on the olive oil, fish oil and butter fat diets did not change significantly (Fig. 2(a,b)). 

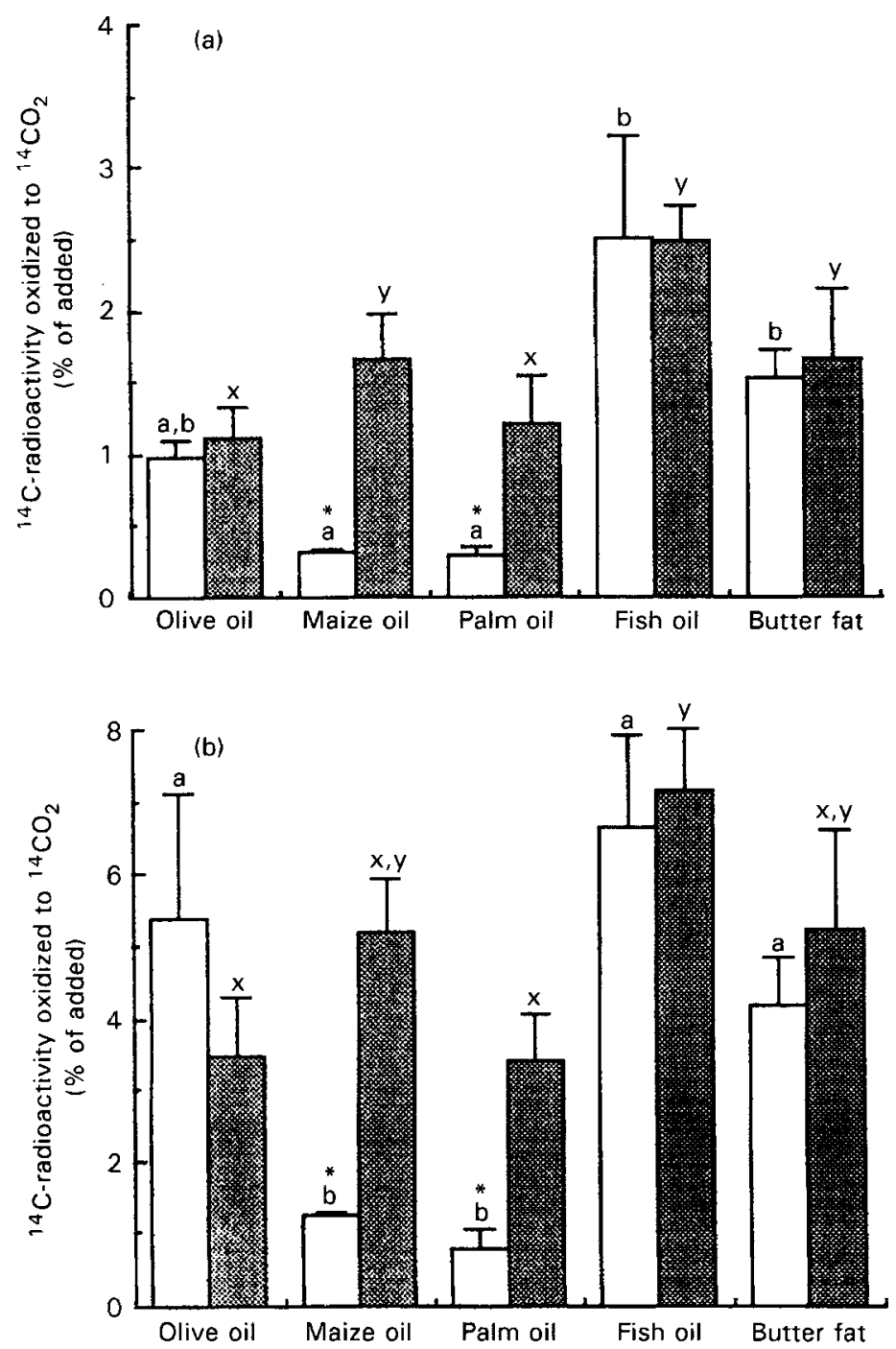

Fig. 2. Oxidation of remnant $\left[{ }^{14} \mathrm{C}\right.$ oleate-labelled lipids to ${ }^{14} \mathrm{CO}_{2}$. Livers were derived from rats fed on a low-fat diet ( $\square$ ) or a fat-supplemented diet (圆) and were perfused with the corresponding $\left[{ }^{14} \mathrm{C}\right]$ oleate-labelled remnants as described on $p .205$. Values are means with their standard errors represented by vertical bars for the following numbers of perfusions; low-fat diets: $n 4$ except maize oil remnants $n 6$; fat-supplemented diet groups: olive oil $n 5$, maize oil $n 6$, palm oil $n 6$, fish oil $n 4$, and butter fat $n 6$. Mean values were significantly different from the corresponding fatsupplemented diet: ${ }^{*} P<0.05$. ${ }^{\mathrm{a}, \mathrm{b}}$ Mean values within the low-fat diet category not sharing a common letter were significantly different, $P<0.05$. ${ }^{x, y}$ Mean values within the fat-supplemented diet category not sharing a common letter were significantly different, $P<0.05$.

The proportion of $\left[{ }^{14} \mathrm{C}\right]$ oleate-labelled remnant lipid added to the perfusate that was converted to phospholipid in $4 \mathrm{~h}$ in livers from fish oil-fed rats was markedly greater than that found in experiments with animals fed on all the other fat diets (Fig. 3(a)). Furthermore, incorporation of radioactivity into phospholipid was increased in livers from rats fed on the fish oil diet as compared with the low-fat diet, but was unchanged on the other fat-supplemented diets. The percentage of the ${ }^{14} \mathrm{C}$ recovered in the liver in phospholipid also showed similar changes (Fig. 3(b)).

\section{Discussion}

The uptake and metabolism of $\left[{ }^{14} \mathrm{C}\right]$ oleate-labelled chylomicron remnants derived from a range of different dietary fats has been investigated using perfused livers from rats fed on the corresponding fat-supplemented diets. The results have been compared with those obtained with livers of rats fed on a standard low-fat diet. This experimental design has enabled the longer-term effects of incorporating different fats into the diet to be studied, and compared with the immediate effects of changes to the fatty acid composition of the chylomicron remnant particles themselves. The dietary fats were added to the standard low-fat rat diet to provide $40 \%$ of the energy content in order to mimic the proportion of fat in the typical Western diet. However, since the addition of fat decreased the content of protein and carbohydrate in the diet by only $17.5 \%$ (by weight), and the allowance of these nutrients in the diet more than compensated for this reduction in terms of the daily requirements for the rat, the supply of essential nutrients in these fat-supplemented diets was considered to be adequate over the period of the experiment (Chwalibog, 1994). 

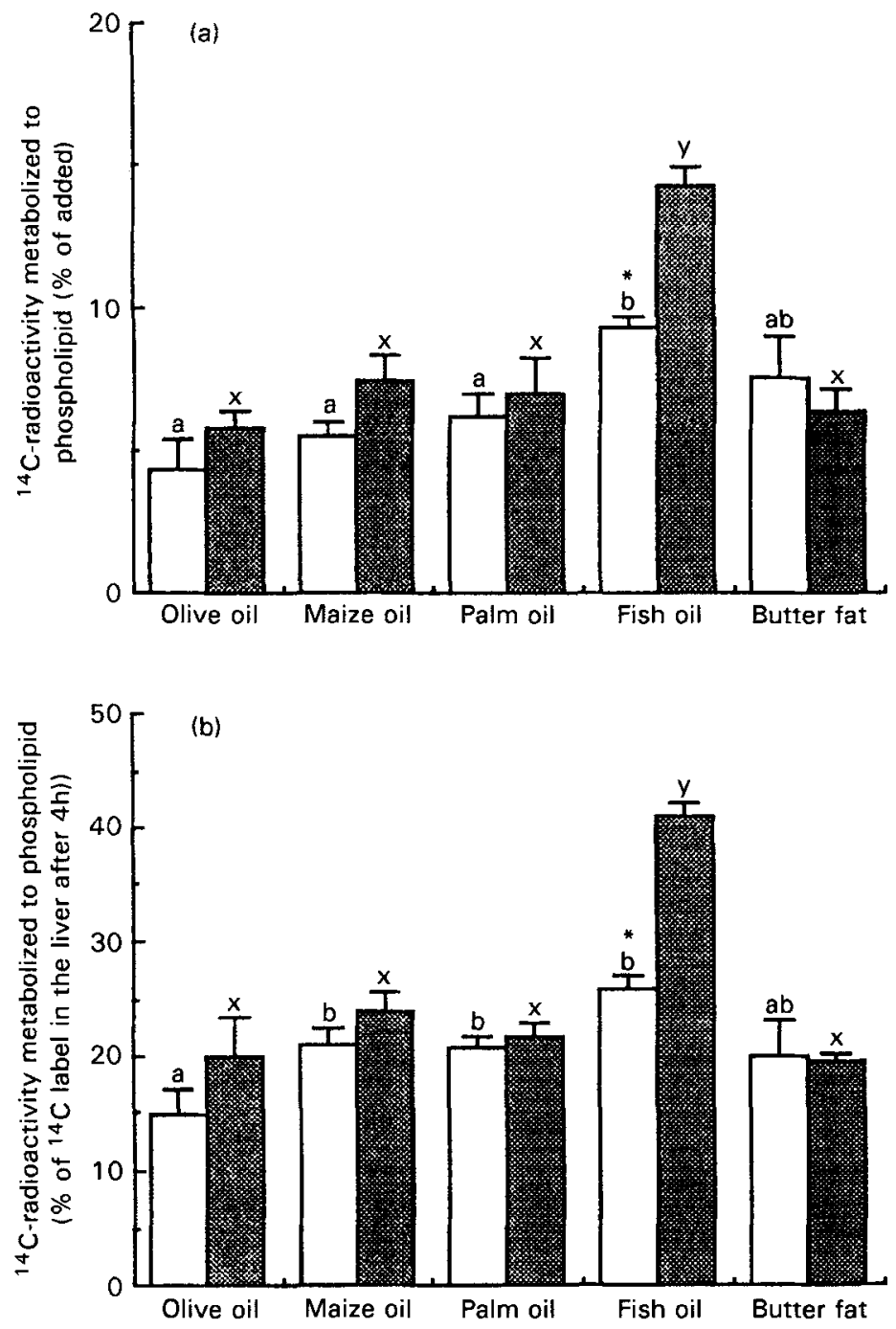

Fig. 3. Net conversion of remnant $\left[{ }^{14} \mathrm{C}\right]$ oleate-labelled lipids into labelled phospholipids. Livers were derived from rats fed on a low-fat diet ( $\square$ ) or a diet supplemented with olive oil, maize oil, palm oil, fish oil, or butter fat (國) and were perfused with the corresponding $\left[{ }^{14} \mathrm{C}\right]$ oleate-labelled remnants as described on p. 205. Values are means with their standard errors represented by vertical bars for the following numbers of perfusions; low-fat diets: $n 4$ except for maize oil remnants $n 6$; fat-supplemented diet groups: olive oil $n 3$, maize oil $n 6$, palm oil $n 4$, bútter fat $n$ 6 , and fish oil $n$ 4. Mean values were significantly different from the corresponding fat-supplemented diet: ${ }^{*} P<0.05$. ${ }^{a, b}$ Mean values within the low-fat diet category not sharing a common letter were significantly different, $P<0.05$. ${ }^{x, y}$ Mean values within the fat-supplemented diet category not sharing a common letter were significantly different, $P<0.05$.

Rats fed on all of the fat-supplemented diets had a reduced non-fasting serum triacylglycerol concentration when compared with rats fed on the standard low-fat diet, although the fish oil diet reduced serum triacylglycerol concentrations to a greater extent than the other fats tested (Table 2). The mechanism for the hypotriacylglycerolaemic effect of the fat-supplemented diets is not clear at present, although the results with the fish oil diet are in agreement with previous work (Rustan et al. 1992). The amount of triacylglycerol in the liver of rats fed on each of the fatsupplemented diets was increased when compared with those fed on a low-fat diet, although the increase was much smaller for rats fed on the fish oil as compared with the other fat-supplemented diets (Table 2). The mechanism for the reduced accumulation of triacylglycerol in livers from rats fed on the fish oil as compared with the other fatsupplemented diets could be due to the stimulatory effects of eicosapentaenoic acid ( $n-3$ polyunsaturated fatty acid present in fish oil) on mitochondrial and peroxisomal fatty acid oxidation (Rustan et al. 1992; Willumsen et al. 1993), and the inhibitory effects of this fatty acid on acyl-CoA: diacylglycerol acyltransferase (EC 2.3.1.20) activity which catalyses an essential step in the pathway of triacylglycerol synthesis (Rustan et al. 1988). In addition, diets high in fish oil have been found to reduce serum non-esterified fatty acid concentrations when compared with other polyunsaturated fats, which would also be expected to decrease their availability for hepatic triacylglycerol synthesis (Singer et al. 1990; Rustan et al. 1992).

$\left[{ }^{14} \mathrm{C}\right]$ oleate-labelled fish oil or butter fat remnants were removed more rapidly from the perfusate than olive, maize, or palm oil remnants by livers from rats fed on a low-fat diet (Fig. 1, Table 3). As the remnants did not differ in any other respect, their differential removal must have been due 
to variations in their fatty acid composition (Lambert $e t$ al. 1995). However, fat-supplementation of the diet abolished the differential hepatic removal of these labelled remnants so that all types of remnants were removed to the same extent (Fig. 1). This was largely due to maize oil diets increasing, and butter fat diets decreasing, the removal of their respective remnants (Fig. 1, Table 3). In the longerterm, adaptive effects of dietary fats may alter the activity of LDL receptors and/or hepatic lipase which have been implicated in hepatic remnant removal (Daggy \& Bensadoun, 1986; Sultan et al. 1990; Choi et al. 1991). Diets rich in both $n-6$ and $n-3$ polyunsaturated fatty acids have been shown to increase hepatic LDL-receptor activity in rats, hamsters and baboons (Papio cynocephalus), while dietary saturated fatty acids have a suppressive effect (Spady \& Dietschy, 1985; Fox et al. 1987; Ventura et al. 1989; Spady \& Woollett, 1990). Since it is believed that this receptor plays a part in the hepatic uptake of chylomicron remnants via the recognition of apoliproprotein E (Choi et al. 1991), this may explain their increased uptake by perfused livers from rats fed on maize oil (enriched in $n-6$ polyunsaturated fatty acids) or the decrease in the livers from rats fed on butter fat (enriched in saturated fatty acids). Hepatic lipase has been shown to promote the uptake of chylomicron remnants by livers from human subjects (Brekenridge et al. 1982) and rats (Daggy \& Bensadoun, 1986). However, as both the activity (Coiffer et al. 1987) and the hepatic expression of mRNA (Bravo et al. 1997) for this enzyme have been found to be increased to a greater extent in rats fed on saturated as compared with $n-6$ polyunsaturated fats, it seems unlikely to be involved in the changes in remnant uptake observed in the present work.

Livers from rats fed on the low-fat diet oxidized more of the $\left[{ }^{14} \mathrm{C}\right]$ oleate-labelled lipids from olive oil, fish oil and butter fat remnants to ${ }^{14} \mathrm{CO}_{2}$ than those from maize and palm oil remnants (Fig. 2). The presence of eicosapentaenoic acid and medium-chain fatty acids (such as myristic acid) in the diet has been shown to increase carnitine palmitoyl transferase-I activity (Pegorier et al. 1988; Surette et al. 1992), although it is not clear whether this can explain the increased oxidation of $\left[{ }^{14} \mathrm{C}\right]$ oleate-labelled lipids from fish oil and butter fat remnants in the relatively short $4 \mathrm{~h}$ period of perfusion. In the longer-term, the increase in oxidation of remnant lipids found with the maize and palm oil supplemented diets in comparison with the low-fat diet (Fig. 2) may be related to adaptive changes in the carnitine palmitoyl transferase-I protein, which has been reported to be markedly less sensitive to malonyl-CoA inhibition in hepatocytes from rats fed on a diet enriched in soyabean oil as compared with a low-fat diet (Pegorier et al. 1988). Comparing the different fat-supplemented diets, it is clear that our results are consistent with previous work suggesting that $n-3$ polyunsaturated fatty acids in fish oil diets are most effective stimulants of mitochondrial and peroxisomal oxidation (Rustan et al. 1992; Willumsen et al. 1993), and this also supports the likelihood of reduced availability of fatty acids for esterification and diminished accumulation of triacylglycerol in the livers of rats fed on this diet (Table 2).

An important observation from the current study is the significantly greater conversion of $\left[{ }^{14} \mathrm{C}\right]$ oleate-labelled lipids into phospholipid from fish oil remnants as compared with the other types of remnants tested in the livers from rats fed on either fat-supplemented or the low-fat diet (Fig. 3). Moir et al. (1995) have previously shown that more $\left[{ }^{14} \mathrm{C}\right]$ oleate from cholesteryl $\left[1-{ }^{14} \mathrm{C}\right]$ oleate-labelled chylomicron remnants was incorporated into hepatic phospholipids when rats were fed on a diet supplemented with fish oil as compared with lard, maize oil or safflower oil. Taken together, these studies demonstrate that fish oil-supplemented diets increase the general rate of phospholipid synthesis in the rat when compared with other dietary fats. These observations could be explained by evidence which shows that eicosapentaenoic acid (present in the fish oil remnants used; Table 1) can directly inhibit diacylglycerol acyltransferase activity in vivo (Coleman \& Bell, 1976; Rustan et al. 1992), and in isolated liver parenchymal cells (Rustan et al. 1988). This would markedly reduce the flux of $\left[{ }^{14} \mathrm{C}\right]$ oleate-labelled lipids towards triacylglycerol synthesis, and as a consequence, significantly increase their utilization for the synthesis of phospholipids.

In summary, the results reported here show that different types of fat given in the diet over a period of $21 \mathrm{~d}$ have differential effects on the hepatic uptake and metabolism of lipids carried in chylomicron remnants of the corresponding fatty acid composition. Compared with the results obtained with perfused livers from rats fed on a low-fat diet, uptake was increased by the maize oil and decreased by the butter fat diet. These changes eliminated the differences in the uptake of remnants of different fatty acid composition found with livers from rats fed on a low-fat diet, so that all the different types of remnants tested were removed at similar rates by the livers of rats adapted to longer-term fat feeding. The hepatic oxidation of $\left[{ }^{14} \mathrm{C}\right]$ oleate-labelled lipids from maize and palm oil remnants was increased by the corresponding fat-supplemented diet. Conversion of the label to phospholipid was markedly increased when the diet was supplemented with fish oil, but not with the other fats tested. These findings clearly indicate that adaptive changes which occur in the rat liver on long-term feeding of different types of fat have effects on the uptake and metabolism of chylomicron remnants which may alter or modify the acute effects of variations in the fatty acid composition of remnant particles.

\section{Acknowledgements}

The financial support of this work by the British Heart Foundation (project no. PG/91140) and the Wellcome Trust (project no. $048022 / \mathrm{Z} / 96$ ) is greatly appreciated.

\section{References}

Bollman JL, Cain JC \& Grindley JH (1948) Techniques for the collection of lymph from the liver, small intestine or thoracic duct of the rat. Journal of Laboratory and Clinical Medicine 33, 1349-1352.

Bravo E, Flora L, Cantafora A, De Luca V, Tripodi M, Avella M, Mayes PA \& Botham KM (1997) Comparison of the uptake and processing of cholesterol from chylomicrons of different fatty acid composition in rats fed high-fat and low-fat diets. European Journal of Biochemistry 246, 92-102. 
Breckenridge WC, Little JA, Alaupovic P, Wang CS, Kuksis A, Kakis G, Lingren F \& Gardiner G (1982) Lipoprotein abnormalities associated with a familial deficiency of hepatic lipase. Atherosclerosis 45, 161-179.

Chwalibog A (1994) Nutrition and the importance of nutrients in animal experiments. In Handbook of Laboratory Animal Science, vol. 1, pp. 169-187 [P Svendsen and J Hau editors]. Boca Raton, FL: CRC Press.

Choi SY, Fong LG, Kirven MJ \& Cooper AD (1991) Use of antilow density lipoprotein receptor antibody to quantify the role of the LDL receptor in the removal of chylomicrons in the mouse in vivo. Journal of Clinical Investigation 88, 1173-1181.

Coiffer E, Paris R \& Lecerf J (1987) Effects of dietary saturated and polyunsaturated fat on lipoprotein lipase and hepatic triacylglycerol lipase activity. Comparative Biochemistry and Physiology 88B, 187-192.

Coleman R \& Bell RM (1976) Triacylglycerol synthesis in isolated fat cells. Studies on the microsomal diacylglycerol acyltransferase activity using ethanol-dispersed diacylglycerols. Journal of Biological Chemistry 251, 4537-4543.

Daggy BP \& Bensadoun A (1986) Enrichment of apolipoproteinB48 in the LDL density class following in vivo inhibition with hepatic lipase. Biochimica et Biophysica Acta 877, 252-261.

De Bruin TWA, Brouwer CB, van Linde-Sibenius-Trip M, Jansen H \& Erkelens DW (1993) Different post-prandial metabolism of olive oil and soybean oil: a possible mechanism of the highdensity lipoprotein conserving effect of olive oil. American Journal of Clinical Nutrition 58, 477-483.

Demacker PNM, Reijnen IGM, Katan MB, Stuyt PMJ \& Stalenhoef AFH (1991) Increased removal of remnants of triglyceride-rich lipoproteins on a diet rich in polyunsaturated fatty acids. European Journal of Clinical Investigation 21, 197-203.

Floren CH \& Nilsson A (1977) Effect of fatty acid unsaturation on chylomicron metabolism in normal and hepatectomised rats. European Journal of Biochemistry 77, 23-30.

Fox JC, McGill HC, Carey KD \& Getz GS (1987) In vivo regulation of the hepatic LDL receptor mRNA in the baboon. Differential effects of saturated and unsaturated fat. Journal of Biological Chemistry 262, 7014-7020.

Harris WS \& Muzio F (1993) Fish oil reduces postprandial triglyceride concentrations without accelerating lipid-emulsion rates. American Journal of Clinical Nutrition 58, 68-74.

Hostmark AT, Lystad E, Haug H \& Eilertsen E (1989) Plasma lipids, lipoproteins, faecal excretion of neutral sterols and bile acids in rats fed various high fat diets or a low fat/high sucrose diet. Journal of Nutrition 119, 356-363.

Kritchevsky D, Tepper SA, Lloyd BA, Davidson LM \& Klurfeld DM (1988) Serum and liver lipids of rats fed cocoa butter, corn oil, palm kernel oil, coconut oil and cholesterol. Nutrition Research 8, 287-294.

Lambert MS, Botham KM \& Mayes PA (1995) Variations in composition of dietary fats affect the hepatic uptake and metabolism of chylomicron remnants. Biochemical Journal 310, 845-852.

Lambert MS, Botham KM \& Mayes PA (1996) Modification of the fatty acid composition of dietary oils and fats on incorporation into chylomicrons and chylomicron remnants. British Journal of Nutrition 76, 435-445.

Mills AR, Cutting WAM, Clark BF, Knox J, Oliver MF \& Bone JM (1986) Davidson and Passmore's Human Nutrition and
Dietetics, 8th ed. Edinburgh and London: Churchill Livingstone.

Moir AMB, Park S \& Zammit YA (1995) Quantification in vivo of the effects of different types of dietary fat on the loci of control involved in hepatic triacylglycerol secretion. Biochemical Journal 308, 537-542.

Nestel PJ \& Scow RO (1964) Metabolism of chylomicrons of different triglyceride composition. Journal of Lipid Research 5 , 46-51.

Pegorier JP, Duee PH, Herbin C, Laulan PY, Blade C, Peret J \& Girard J (1988) Fatty acid metabolism in hepatocytes isolated from rats adapted to high-fat diets containing long- or mediumchain triacylglycerols. Biochemical Journal 249, 801-806.

Redgrave TG (1970) Formation of cholesteryl ester-rich particulate lipid during metabolism of chylomicrons. Journal of Clinical Investigation 49, 465-471.

Rustan AC, Christiansen EN \& Drevon CA (1992) Serum lipids, hepatic glycerolipid metabolism and peroxisomal fatty acid oxidation in rats fed omega- 3 and omega- 6 fatty acids. Biochemical Journal 283, 333-339.

Rustan AC, Nossen JO, Christiansen EN \& Drevon CA (1988) Eicosapentaenoic acid reduces hepatic synthesis and secretion of triacylglycerol by decreasing the activity of acyl-coenzyme A:1,2-diacylglycerol acyltransferase. Journal of Lipid Research 29, 1417-1426.

Singer P, Wirth M \& Berger I (1990) A possible contribution of decrease in free fatty acids to low triglyceride levels after diets supplemented with $n-6$ and $n-3$ polyunsaturated fatty acids. Atherosclerosis 83, 167-175.

Spady DK \& Dietschy JM (1985) Dietary saturated triacylglycerols suppress hepatic low density lipoprotein receptor activity in the hamster. Proceedings of the National Academy of Sciences USA 82, 4526-4530.

Spady DK \& Woollett LA (1990) Interaction of dietary saturated and polyunsaturated triglycerides in regulating the processes that determine plasma low density lipoprotein concentrations in the rat. Journal of Lipid Research 31, 1809-1819.

Sultan F, Lagrange D, Jansen H \& Griglio S (1990) Inhibition of hepatic lipase activity impairs chylomicron remnant removal in rats. Biochimica et Biophysica Acta 1042, 150-152.

Surette ME, Whelan KS, Broughton KS \& Kinsella JE (1992) Evidence for mechanisms of the hypotriglyceridaemic effect of n-3 polyunsaturated fatty acids. Biochimica et Biophysica Acta 1126, 199-205.

Trinder P (1969) Determination of glucose in blood using glucose oxidase with an alternative oxygen acceptor. Annals of Clinical Biochemistry 6, 24-29.

Ventura MA, Woollett LA \& Spady DK (1989) Dietary fish oil stimulates hepatic low density lipoprotein transport in the rat. Journal of Clinical Investigation 84, 528-537.

Weintraub MS, Zechner R, Brown A, Eisenberg S \& Breslow JL (1988) Dietary polyunsaturated fats of the omega-6 and omega-3 series reduce postprandial lipoprotein levels. Chronic and acute effects of fat saturation on postprandial lipoprotein metabolism. Journal of Clinical Investigation $\mathbf{8 2}$, 1884-1893.

Willumsen N, Hexeberg S, Skorve J, Lundquist M \& Berge RK (1993) Docosahexaenoic acid shows no triglyceride-lowering effects but increases peroxisomal fatty acid oxidation in liver of rats. Journal of Lipid Research 34, 13-22. 